\title{
Terrestrial gastropod diversity, distribution and abundance in areas with and without anthropogenic disturbances, Northeast Algeria
}

\author{
HADJER BELHIOUANI ${ }^{1, \boldsymbol{v}}$, MOHAMED EL-HADEF EL-OKKI ${ }^{1,2}$, FATIMA-ZOHRA AFRI-MEHENNAOUI ${ }^{1}$, \\ LEILA SAHLI, ${ }^{1, \vee \varphi}$ \\ ${ }^{1}$ Laboratory of Biology and Environment, University of Mentouri Brothers Constantine 1. Rue Ain El Bey, 25000 Constantine, Algeria. \\ "email: belhiouani.hadjer@umc.edu.dz,"vs sahli.leila@umc.edu.dz \\ ${ }^{2}$ Nutrition, Food and Agri-Food Technology Institute, University of Mentouri Brothers Constantine 1, 25000 Constantine, Algeria
}

Manuscript received: 12 October. Revision accepted: 25 December 2018.

\begin{abstract}
Belhiouani H, El-Hadef El-Okki M, Afri-Mehennaoui FZ, Sahli L. 2019. Terrestrial gastropod diversity, distribution and abundance in areas with and without anthropogenic disturbances. Biodiversitas 20: 243-249. The objective of this study was to establish an inventory of terrestrial gastropods from different sites in the northeast of Algeria. Several points were sampled from five various areas relatively affected by human activity. Areas prospected were an industrial area (El-Hadjar, Annaba), a mining area (Djebel Hamimat, Oum-El-Bouaghi), an urban area (B'kira, Constantine), a mountainous area (Ibn Ziad, Constantine) and a sub-mountainous area (Ibn Badis, Constantine). A total of 11 species and 2632 individual land snails belonging to six molluscan families (Helicidae, Hygromiidae, Sphincterochilidae, Achatinidae, Enidae, and Pomatiidae) and 10 genera were found in all habitats. The highest density was recorded in the mountainous area with 1270 individuals and 10 species, whereas the lowest value was recorded in the mining and the industrial areas with 3 and 4 species respectively. The malacofaunal diversity was also determined, Shannon's index, Simpson's index, and equitability index are higher in the mountainous zone of Ibn Ziad with 1.87, 0.82 and 0.78 respectively, and lower in the mining area of Djebel Hamimat, with $0.60,0.33$, and 0.54 . The dispersion and density of species appear to be contingent upon several factors among which soil properties, height, climate conditions and certainly anthropogenic disturbance.
\end{abstract}

Keywords: Anthropogenic activity, biodiversity, richness, terrestrial gastropod

\section{INTRODUCTION}

The analysis of biocenosis biodiversity, structure and settlements constitute a main field of ecology; it is also the foundation of any sustainable development. Nevertheless, in recent years, biodiversity is chiefly threatened by anthropogenic activities such as demography, excessive consumption, technology, and pollution. These factors are the principal contributors to major changes to the structure of biological compartments and the dysfunction of the surrounding ecosystems including their soils. Researchers are increasingly concerned with vertebrates' biodiversity, but they tend to neglect invertebrates, especially soildwelling invertebrates (such as earthworms, ants, termites, and land snails), even though they perform a prominent role in maintaining vigorous soils and balanced ecosystems.

Worldwide, terrestrial gastropods have been estimated to number about 35,000 extant species (Solem 1984; Van Bruggen 1995). They represent the most diverse phylum after arthropods and the most threatened by extinction. Additionally, they are viewed as a fundamental indicator of ecosystem health because they help to break down and recycle decaying plant materials, and as a result, they serve as food source for amphibians, reptiles, small mammals, birds and arthropods (Barker 2001). Another significant role assumed by land snails is calcium uptake from the soil and organic matters and the transfer of this nutrient (and potentially others) to higher trophic levels, as suggested by Beeby (1991), and Adams and Wall (2000) The widespread occurrence of terrestrial gastropods is clear evidence of their successful adaptation to different environments. They colonized most land environment ranging from low lands to high mountains, including humid to arid biotopes of tropical to subarctic areas (Frýda and Rohr 2004)

Terrestrial snails are divided into two large groups, the informal group Pulmonata and the superorder Caenogastropoda that includes most species of prosobranchs (Pechenik 2005). The informal group Pulmonata comprises three main suborders that live in different habitats: Basommatophora, Stylommatophora, and Systellomatophora (Bouchet et al. 2005). This study deals with representatives of the Caenogastropoda (1 species) and Stylommatophora (10 species).

In Algeria, land snail species were examined by either old studies (Bourguignat 1864; Poiret 1789), or more recent ones in northwestern Algeria (Tlemcen), where Damerdji (2008) analyzed malacofauna diversity. Boudechiche (2007), focused on helicoidal biodiversity in El-Kala (northeast of Algeria). The research of Larba and Soltani (2014) approached gastropods as bioindicators of the environmental quality in the northeast of Algeria and ultimately, Bouaziz-Yahiatene and Medjdoub-Bensaad' report, in 2016, investigated the diversity of the malacofauna present in the Great Kabylia (north of Algeria). Nevertheless, the regions of Constantine and Oum-El-Bouaghi in northeastern Algeria have been so far a virgin terrain. Furthermore, the comparison of populations of gastropods in environments relatively affected by human 
activity has not previously been established.

Given the importance of these organisms, the present paper presents an examination of the gastropods in five zones in the northeast of Algeria, characterized by different levels of anthropogenous activity. For this purpose, we conducted a quantitative assessment of the diversity, distribution, and abundance of terrestrial gastropods across numerous representative plots, taking into consideration anthropogenic influence.

\section{MATERIALS AND METHODS}

\section{Study areas}

Land snail samples were taken in five different habitats located in the Algerian northeast. These habitats are characterized by a more or less significant anthropogenic influence. Each habitat contained several plots distributed in a random way. The table below sums up the characteristics of every site (Table 1 ). The figure 1 situates geographically the sites in the study area.

\section{Sampling methods and identification}

An approximately 1 to 8 square meter quadrat was established using a tape measure for every plot. In every plot, land snails were searched for by eye. This visual search method enabled direct observation of individual snails present in their habitat, e.g., on tree trunks, under wind fallen-woods, stones, on old walls etc., for approximately one hour depending on habitat heterogeneity and species richness. This method is very interesting and complementary; it allowed us to draw up the first list quickly.

Only live specimens were picked. Slugs were omitted because their activity depends largely on weather conditions (Rollo 1991). The samples obtained were temporarily housed in labeled plastic bags for being examined. The identifications then started by cleaning the shells so that the characters for identification were not masked. They also were sorted beforehand by morphological resemblance. Thus, we took in consideration the size, the shape, the coloring and the ornamentation of the shell. The identification was grounded in the key features cited by Bouchet et al. (2005) and (Barker 2001).

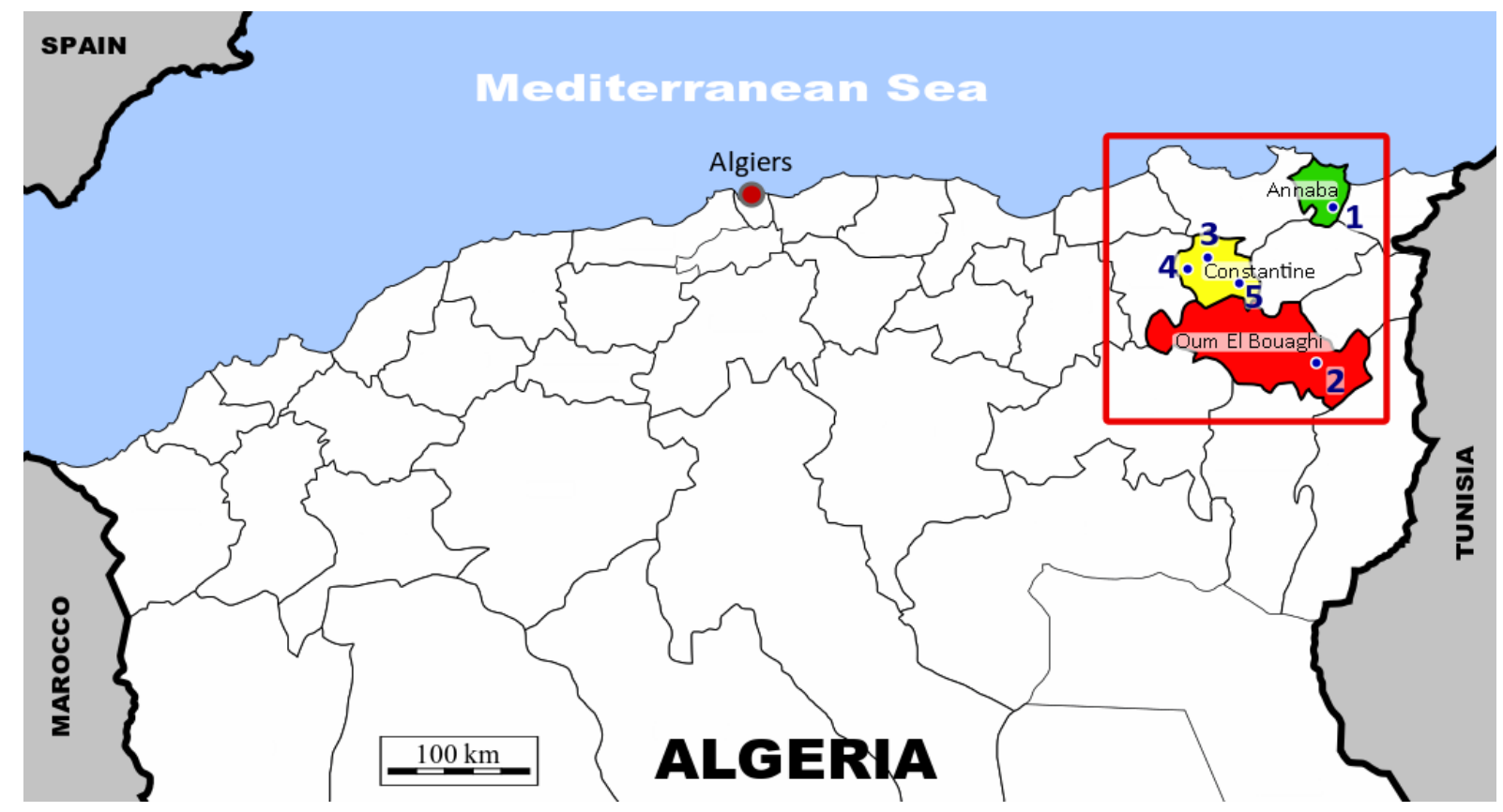

Figure 1. Location of the five sites of survey in northeastern Algeria

Table 1. Characteristics of the study areas in northeastern Algeria

\begin{tabular}{|c|c|c|c|}
\hline \multirow{3}{*}{$\begin{array}{l}\text { Site } \\
1\end{array}$} & Characteristics & Coordinates & Height \\
\hline & El-Hadjar (Annaba department): an industrial area characterized by the presence of a steel factory: & $36^{\circ} 47^{\prime} 44^{\prime \prime} \mathrm{N}$ & $52 \mathrm{~m}$ \\
\hline & Arcelor Mittal of El-Hadjar. & 741’02’’E & \\
\hline 2 & $\begin{array}{l}\text { Djebel Hamimat, (Oum-El-Bouaghi department): On the side of Djebel Hamimat which contains an } \\
\text { abandoned mining site for antimony. }\end{array}$ & $\begin{array}{l}35^{\circ} 59^{\prime} 03^{\prime}{ }^{\prime} \mathrm{N} \\
7^{\circ} 12^{\prime} 04^{\prime}, \mathrm{E}\end{array}$ & $878 \mathrm{~m}$ \\
\hline 3 & $\begin{array}{l}\text { B'kira (Constantine department): an urban area crossed by the national road } \mathrm{N}^{\circ} 03 \text {, a principal road with } \\
\text { heavy traffic, which connects the city of Constantine to Hamma Bouziane. }\end{array}$ & $\begin{array}{l}36^{\circ} 23^{\prime} 51^{\prime \prime} \mathrm{N} \\
6^{\circ} 36^{\prime} 49^{\prime \prime} \mathrm{E}\end{array}$ & $627 \mathrm{~m}$ \\
\hline 4 & $\begin{array}{l}\text { Ibn Badis (Constantine department): a sub-mountainous zone, under the anthropogenic influence: the } \\
\text { presence of quarries for aggregates. }\end{array}$ & $\begin{array}{l}36^{\circ} 17^{\prime} 211^{\prime \prime} \mathrm{N} \\
6^{\circ} 53^{\prime} 17^{\prime \prime} \mathrm{E}\end{array}$ & $916 \mathrm{~m}$ \\
\hline 5 & Ibn Ziad (Constantine department): a mountainous zone, far from any anthropogenic activity. & $\begin{array}{l}36^{\circ} 21^{\prime} 05^{\prime \prime} \mathrm{N} \\
6^{\circ} 27^{\prime} 45^{\prime \prime} \mathrm{E}\end{array}$ & $993 \mathrm{~m}$ \\
\hline
\end{tabular}




\section{Data analysis}

After identification of the species, the harvested individuals were counted and constancy, as well as several indices of diversity, were calculated.

The constancy index $(C)$ for each species is calculated according to Dajoz (1985):

$$
(C)=\frac{p \times 100}{P}
$$

Where $p$ is the number of samples in which a given species occurs and $\mathrm{P}$ is the total number of samples analyzed. Species can be classified into three different constancy categories: constant $(\mathrm{C} \geq 50 \%)$, accessory $(25 \%$ $<\mathrm{C}<50 \%)$ and accidental $(\mathrm{C}<25 \%)$ (Dajoz, 1985).

Diversity indices provide interesting pieces of information about a community structure. They aim to describe general properties of communities that allow us to compare different regions, taxa, and trophic levels (Morris et al. 2014). Hence, several biodiversity indices were determined during the study:

Shannon's index $\left(\boldsymbol{H}^{\prime}\right)$ : A common biodiversity index based on the rationale that the diversity, or information, in a natural system can be measured in a similar way to the information contained in a code or message. It assumes that individuals are randomly sampled from an infinitely large community and that all species are represented in the sample. It is calculated from the following equation (Magurran 2004):

$$
\left(H^{\prime}\right)=\sum_{i=1}^{s} p_{i} \ln p_{i}
$$

Where $\mathrm{p}_{\mathrm{i}}$ is the proportion of individuals found of species i. We can estimate this proportion as $p_{i}=n_{i} / N$, where $n_{i}$ is the number of individuals in species $i$ and $N$ is the total number of individuals in the community (Magurran 2004).

Simpson's index $(\boldsymbol{D})$ : this index is less sensitive to richness and more sensitive to evenness (Colwell, 2009). It computes the probability of two randomly sampled species to belong to different species (Siddique et al. 2010):

$$
(D)=1-\sum_{i=1}^{s} p_{i}{ }^{2}
$$

Where again $p_{i}$ is the proportion of individuals found in species $i$, and $p_{i}=n_{i} / N$, where $n_{i}$ is the number of individuals in species $\mathrm{i}$ and $\mathrm{N}$ is the total number of individuals in the community (Magurran 2004).

Equitability index $(\boldsymbol{J})$ used to assess the degree of species equality in a community (Mulder et al. 2004):

$$
(J)=\frac{H^{\prime}}{H^{\prime} \max }=\frac{H^{\prime}}{\ln S}
$$

Where $H^{\prime}$ is Shannon's diversity index value and $\mathrm{S}$ is the species richness of the sample. It assumes a value between 0 and 1 with 1 being complete evenness (Mulder et al. 2004).

\section{RESULTS AND DISCUSSION}

\section{Sampling results}

This study allowed us to list, in total 2632 individuals represented by 11 species of pulmonate land snails distributed among 10 genera and 6 families: Helicidae, Hygromiidae, Sphincterochilidae, Achatinidae, Enidae, and Pomatiidae (Table 2). The Helicidae is the richest family with four species: Massylaea vermiculata (Müller 1774), Cornu aspersum (Müller 1774), Cantareus apertus (Born 1778), and Theba pisana (Müller 1774). The Hygromiidae are represented by two species, Xerosecta cespitum (Draparnaud 1801), and Ganula flava (Terver 1839). The Sphincterochilidae is also represented by two species: Sphincterochila candidissima (Draparnaud 1801), and Sphincterochila otthiana (Forbes 1838). All the other families (i.e., Subulinidae, Enidae, and Pomatiidae) include one species each namely: Rumina decollata (Linnaeus 1758), Mastus pupa (Linnaeus 1758), and Tudorella rubicunda (Pallary 1936) (table 2).

Figure 2 shows frontal, back and profile photos of empty shells of all species collected throughout the study. The systematic list of all the species collected during the study is represented in Table 2.

\section{Distribution and structure of terrestrial gastropod communities}

Table 3 summarizes the percentages (\%) of species harvested in all areas. The spatial distribution of harvested individuals differs from a site to another. The survey results indicate a maximum of 1270 out of 2632 participants at Ibn Ziad. This mountainous region is also considered the richest with 10 species, distributed among six families (Helicidae, Hygromiidae, Sphincterochilidae, Achatinidae, Enidae, and Pomatiidae), and 9 genera (Massylaea, Cornu, Theba, Sphincterochila, Rumina, Xerosecta, Mastus, Ganula and Tudorella).

The site of Ibn Ziad is followed by the sub-mountainous area of Ibn Badis, with 321 individuals belonging to 8 species, 4 families (Helicidae, Sphincterochilidae, Achatinidae, and Pomatiidae), and 7 genera (Massylaea, Cornu, Cantareus, Theba, Sphincterochila, Rumina and Tudorella).

Next comes B'kira, the urban area with a value of 207 individuals spread between 6 species, 3 families (Helicidae, Hygromiidae, and Achatinidae) and 4 genera (Cantareus, Cornu, Theba, Xerosecta, and Rumina).

The industrial area (El-Hadjar) and the mining area of antimony (Djebel Hamimat) proved to be the poorest sites with four and three species respectively. Both are represented by two families (Helicidae and Achatinidae), and five genera (Massylaea, Cantareus, Cornu, Theba, and Rumina). 


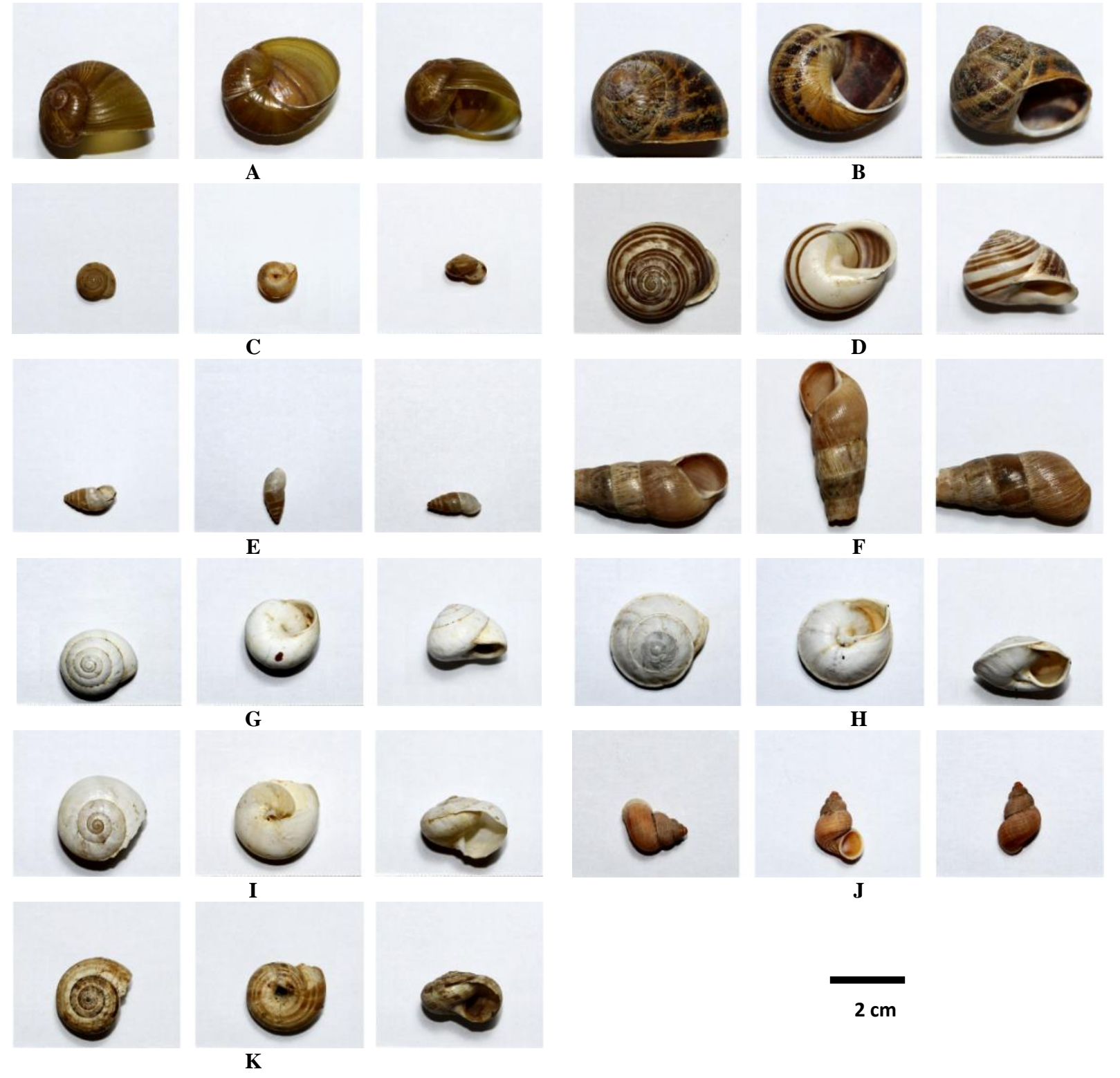

Figure 2. Frontal, back and profile photos of empty shells of all species harvested during the study. A. Cantareus apertus (Born 1778), B. Cornu aspersum (Müller 1774), C. Ganula flava (Terver 1839), D. Massylaea vermiculata (Müller 1774), E. Mastus pupa (Linnaeus 1758), F. Rumina decollata (Linnaeus 1758), G. Sphincterochila candidissima (Draparnaud 1801), H. Sphincterochila otthiana (Forbes 1838), I. Theba pisana (Müller 1774), J. Tudorella rubicunda (Pallary 1936), K. Xerosecta cespitum (Draparnaud 1801)

Table 2. Systematic list of terrestrial gastropods species collected during the study

\begin{tabular}{|c|c|c|c|c|c|c|}
\hline 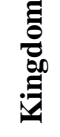 & $\frac{\Xi}{\mathbb{E}}$ & $\frac{v}{\tilde{E}}$ & ơ & 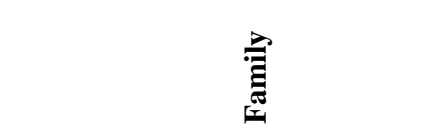 & ڤ̆ & $\frac{\mathscr{e}}{\mathscr{E}}$ \\
\hline \multirow{10}{*}{ 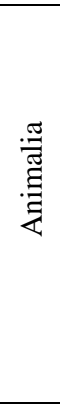 } & \multirow{10}{*}{$\begin{array}{l}\tilde{J} \\
\stackrel{0}{\Xi} \\
\bar{\Xi} \\
\Sigma\end{array}$} & \multirow{10}{*}{ 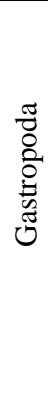 } & \multirow{10}{*}{ 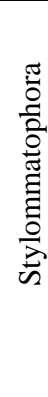 } & Helicidae (Rafinesque 1815) & Cantareus (Risso 1826) & Ca. apertus (Born 1778) \\
\hline & & & & & Cornu (Born 1778) & Co. aspersum (Müller 1774) \\
\hline & & & & & Massylaea (Möllendorff 1898) & Ms. vermiculata (Müller 1774) \\
\hline & & & & & Theba (Risso 1826) & Th. pisana (Müller 1774) \\
\hline & & & & Hygromiidae (Tryon 1866) & Ganula (Gittenberger 1969) & G. flava (Terver 1839) \\
\hline & & & & & Xerosecta (Monterosato 1892) & X. cespitum (Draparnaud 1801) \\
\hline & & & & Sphincterochilidae (Zilch 1960) & Sphincterochila (Ancey 1887) & $\begin{array}{l}\text { S. candidissima (Draparnaud 1801) } \\
\text { S. otthiana (Forbes 1838) }\end{array}$ \\
\hline & & & & Achatinidae (Swianson 1840) & Rumina (Risso 1826) & R. decollata (Linnaeus 1758) \\
\hline & & & & Enidae (Woodward, 1903 (1888) & Mastus (Beck 1837) & Mt. pupa (Linnaeus 1758) \\
\hline & & & & Pomatiidae (Newton, 1891 (1828) & Tudorella (Fischer 1885) & Tu. rubicunda (Pallary 1936) \\
\hline
\end{tabular}


Table 3. Percent (\%) frequencies of species collected in all areas

\begin{tabular}{lccccc}
\hline \multicolumn{1}{c}{ Species } & $\begin{array}{c}\text { El- } \\
\text { Hadjar }\end{array}$ & $\begin{array}{c}\text { Djebel } \\
\text { Hamimat }\end{array}$ & B'kira & $\begin{array}{c}\text { Ibn } \\
\text { Badis }\end{array}$ & $\begin{array}{c}\text { Ibn } \\
\text { Ziad }\end{array}$ \\
\hline Ca. apertus & 10.43 & 0 & 33.33 & 2.8 & 0 \\
Co. aspersum & 13.5 & 0 & 48.31 & 5.3 & 19.45 \\
G. flava & 0 & 0 & 0 & 0 & 0.16 \\
Ms. vermiculata & 73.85 & 79.92 & 4.35 & 71.65 & 28.19 \\
Mt. pupa & 0 & 0 & 0 & 0 & 0.24 \\
R. decollate & 2.22 & 16.06 & 12.56 & 2.18 & 15.35 \\
S. candidissima & 0 & 0 & 0 & 9.66 & 4.02 \\
S. otthiana & 0 & 0 & 0 & 5.92 & 10.87 \\
T. rubicund & 0 & 0 & 0 & 0.31 & 12.91 \\
Th. Pisana & 0 & 4.02 & 0.97 & 2.18 & 8.58 \\
X. cespitum & 0 & 0 & 0.48 & 0 & 0.24 \\
S=11 & $\mathbf{4}$ & $\mathbf{3}$ & $\mathbf{6}$ & $\mathbf{8}$ & $\mathbf{1 0}$ \\
Totals & $\mathbf{5 8 5}$ & $\mathbf{2 4 9}$ & $\mathbf{2 0 7}$ & $\mathbf{3 2 1}$ & $\mathbf{1 2 7 0}$ \\
(N= 2632 inds) & & & & & \\
\hline
\end{tabular}

Table 4. Constancy (\%) of terrestrial gastropods collected in study areas

\begin{tabular}{lcccccc}
\hline \multicolumn{1}{c}{ Species } & $\begin{array}{c}\text { El- } \\
\text { Hadjar Hamimat }\end{array}$ & $\begin{array}{c}\text { Djebel } \\
\text { B'kira }\end{array}$ & $\begin{array}{c}\text { Ibn } \\
\text { Badis }\end{array}$ & $\begin{array}{c}\text { Ibn } \\
\text { Ziad }\end{array}$ & $\begin{array}{c}\text { Constancy } \\
(\%)\end{array}$ \\
\hline Ca. apertus & 1 & 0 & 1 & 1 & 0 & 60 \\
Co. aspersum & 1 & 0 & 1 & 1 & 1 & 80 \\
G. flava & 0 & 0 & 0 & 0 & 1 & 20 \\
Ms. vermiculata & 1 & 1 & 1 & 1 & 1 & 100 \\
Mt. pupa & 0 & 0 & 0 & 0 & 1 & 20 \\
R. decollate & 1 & 1 & 1 & 1 & 1 & 100 \\
S. candidissime & 0 & 0 & 0 & 1 & 1 & 40 \\
S. otthiana & 0 & 0 & 0 & 1 & 1 & 40 \\
Th. pisana & 0 & 1 & 1 & 1 & 1 & 80 \\
Tu. rubicunda & 0 & 0 & 0 & 1 & 1 & 40 \\
X. cespitum & 0 & 0 & 1 & 0 & 1 & 40 \\
\hline
\end{tabular}

Table 5. Species richness, density, and biodiversity indices of terrestrial gastropods collected in the study areas

\begin{tabular}{lccccc}
\hline \multicolumn{1}{c}{ Species } & $\begin{array}{c}\text { El- } \\
\text { Hadjar }\end{array}$ & $\begin{array}{c}\text { Djebel } \\
\text { Hamimat }\end{array}$ & B'kira & $\begin{array}{c}\text { Ibn } \\
\text { Badis }\end{array}$ & $\begin{array}{c}\text { Ibn } \\
\text { Ziad }\end{array}$ \\
\hline Species richness & 11 & 8 & 6 & 4 & 3 \\
Density & 211.7 & 53.5 & 34.5 & 97.5 & 41.5 \\
Simpson index $(D)$ & 0.76 & 0.39 & 0.37 & 0.16 & 0.15 \\
Shannon index $\left(H^{\prime}\right)$ & 1.54 & 0.75 & 0.61 & 0.25 & 0.23 \\
Equitability $(J)$ & 0.90 & 0.59 & 0.65 & 0.30 & 0.21 \\
\hline
\end{tabular}

\section{Density and constancy of terrestrial gastropods}

The population of Ms. vermiculata owns individual's largest number of 1228 individuals which represents $46.66 \%$ of the total number of individuals (table 4 ). It is the most abundant species. It is followed by Co. aspersum with 443 individuals $(16.83 \%)$ and $R$. decollata with 281 specimens $(10.68 \%)$. The lowest number of individuals were registered for populations of G. flava, Mt. pupa, and $X$. cespitum represented by less than $1 \%$.

Table 3 represents constancy of terrestrial gastropods collected in study areas. According to the interpretation of
Dajoz (1985), and with a constancy of $100 \%, M s$. vermiculata and $R$. decollata are constant species, as well as Co. aspersum, Th. pisana (80\%), and Ca. apertus $(60 \%)$. The species $S$. otthiana, S. candidissima, X. cespitum and $T u$. rubicunda are considered as accessory species with a constancy of $40 \%$. Finally, Mt. pupa and G. flava are accidental species with a constancy of $20 \%$.

\section{Biodiversity indices}

With 1270 individuals represented by 10 species, the area of Ibn Ziad is the most diversified and the richest site. It is followed by Ibn Badis and B'kira, the submountainous and the urban area with 8 and 6 species respectively. Comes next, El-Hadjar and Djebel Hamimat (the industrial and the mining area) with 4 and 3 species respectively. Table 5 abbreviates species richness, density, and biodiversity indices of terrestrial gastropods collected in the study areas.

The highest mean values of both Shannon's and Simpson's indices were recorded in the mountainous area of Ibn Ziad with 1,54 and 0,76 respectively. However, the lowest mean values, which are 0,15 and 0,23 , were recorded in Djebel Hamimat (mining area). By calculating the equitability, we noticed that the species are relatively more equally distributed in the mountainous area of Ibn Ziad with a rate of 0,90 in comparison with the sites of Ibn Badis $(J=0,59)$ and Djebel Hamimat $(J=0,21)$.

Those results show that the distribution of the species in both Ibn Badis and Djebel Hamimat is very uneven. Indeed, this is due to the omnipresence of the species $M s$. vermiculata, the most abundant species in those areas (with rates of $71.65 \%$ and $79.92 \%$ respectively), while the area of Ibn Ziad benefits of a more evenly distributed population.

\section{Discussion}

This study aimed to establish an inventory of land snails present in five various areas situated in the Northeast of Algeria. Every single site owns different characteristics. Indeed, we had an urban area, an industrial area, a mining area, a sub-mountainous area with anthropogenic influence, and a mountainous area. Thus, we studied the distribution of land snails according to the presence or the absence of anthropogenic activity and its importance.

The results obtained demonstrate that the densest and the richest region is the area of Ibn Ziad with 1270 individuals and 11 species, of which Ms. vermiculata (28.19\%), Co. aspersum $(19.45 \%)$ and $R$. decollata $(15.35 \%)$ are the three most common ones. It is the only area, which contains constant, secondary and accidental species. Indeed, it is located in mountains at an altitude of $993 \mathrm{~m}$ far from any disturbing source. Some land snails are eminent indicators of environmental conditions; for instance, there are species that are strictly limited to undisturbed ecosystems while others are indicative of habitats degraded by human exploitation. The presence or absence of land snails could also be associated with several environmental conditions including soil properties and climate parameters (Ondina et al. 2004). 
Cornu aspersum is a ubiquitous species, it is found in a large range of habitats and climates, from Mediterranean to temperate, oceanic and tropical (Chevallier 1977; Neubert 2014). During the survey, it was found almost everywhere. It is the same case for the pulmonate land snail $R$. decollata, which is a highly invasive gastropod native present everywhere in the Mediterranean area and adapted to arid conditions (De Francesco and Lagiglia 2007; Matsukuma 2009; Prévot 2013). The genus Tudorella occurs along the western Mediterranean coasts from southern France and the Iberian peninsula to Malta (Southern Europe), and from Morocco to Libya in Northern Africa (Sacchi 1958). A recent study who revised the taxonomy of this genus demonstrated that the species $T u$. rubicunda is an endemic species in Algeria, in fact, it belongs to clade 7 phylogenetic analysis (Pfenninger et al. 2010). Its existence is confirmed in the region of Constantine, exactly in Ibn Badis and Ibn Ziad (with a rate of $0.31 \%$ and $12.91 \%$ respectively).

Previous researches carried out in northeast Algeria demonstrated the presence of Th. pisana in El Kala (Larba and Soltani 2013). This species occurred at Djebel Hamimat, B'kira, Ibn Badis, and Ibn Ziad. The species Th. pisana is considered as invasive, it has been widely dispersed through human activities. The Mediterranean and adjacent Atlantic coasts are considered as natural range of this species (Däumer et al. 2012).

The works led by Damerdji (2008) in the region of Tlemcen (Northwest Algeria) described numerous species, among whom: $S$. candidissima, which is one of the most widespread species of the family, and in the west of the country, its distribution is governed mainly by climatic and trophic factors. S. otthiana has been reported from Ibn Badis and Ibn Ziad, it is an endemic species and widely distributed in Algeria (Abbes et al. 2011).

Djebel Hamimat and El-Hadjar proved to be the poorest sites with 3 and 4 species respectively. In fact, Djebel Hamimat is situated near to an abandoned mining area for antimony existing since the colonial era, whose effects are until today evident. An earlier study led by RachedMosbah (1993) revealed that the soils in this region contain high concentrations of trace metal elements, notably arsenic, zinc, lead, and antimony. The concentrations in the soil are abnormally high near mineshafts, and this visibly, led to a reduction in the rate of biodiversity in the region.

The second area is situated near to Arcelor-Mittal steelworks (El-Hadjar, Annaba) and previous studies demonstrated that the metallic pollution is preponderant in this region (Abdennour et al. 2000; Beldi et al. 2006; Semadi and Deruelle 1993). Added to this is the transport of pollutants via winds, for example, transport of $\mathrm{Cd}$ in phosphate fertilizers (Hamon et al. 1998), gastropod biodiversity is, consequently, considerably reduced in both localities. We noticed that these two areas are dominated by $M s$. vermiculata with a percentage of $79.92 \%$ (Djebel Hamimat) and $73.85 \%$ (El-Hadjar), respectively. It proves the capacity of this species to adapt itself to strongly polluted sites. A study showed that the species Ms. vermiculata is useful as a bioindicator organism and support the application of this ecotoxicological approach for assessing the biologic impact of pollutants (Itziou and Dimitriadis 2011).

In conclusion, the inventory established in five different sites situated in the east of Algeria reported 11 species of terrestrial gastropods. Their specific richness varies between sites. The highest value of species richness was registered in Ibn Ziad, which is occupying an area far from any anthropogenic disturbance. Helicidae is the richest family with seven species. Ms. vermiculata is the most abundant species in all sites. The difference in distribution and abundance of the species may be associated with habitat heterogeneity, soil properties, height, climate conditions, and above all, the negative effect of the various anthropogenic activities in these areas. As an outlook, it would be interesting to investigate the causes of the decline of biodiversity from one region to another. It will be interesting to establish the physicochemical parameters of the soil in order to make the link between the distribution of these gastropods and the conditions of the environment in which they live. It would also be interesting to draw up an annotated checklist of all species encountered to date in these areas.

\section{ACKNOWLEDGEMENTS}

The authors would like to thank Dr. Eike Neubert of Natural History Museum Bern for his advice and his assistance for gastropod identification.

\section{REFERENCES}

Abbes I, Nouira S, Neubert E. 2011. Sphincterochilidae from Tunisia, with a note on the subgenus Rima Pallary, 1910 (Gastropoda, Pulmonata). ZooKeys 151: 1-15.

Abdennour C, Smith BD, Boulakoud MS, Samraoui B, Rainbow PS. 2000. Trace metals in marine, brackish and freshwater prawns (Crustacea, Decapoda) from northeast Algeria. Hydrobiologia 432: 217-227.

Adams GA, Wall DH. 2000. Biodiversity above and below the surface of soils and sediments: linkages and implications for global change. BioScience 50: 1043-1048.

Barker GM. 2001. The Biology of Terrestrial Molluscs. CABI Publishing, New York.

Beeby A. 1991. Toxic metal uptake and essential metal regulation in terrestrial invertebrates: A review. In: Newman MC, McIntosh AW (Eds) Metal Ecotoxicology: Concepts and Applications. Lewis Publishing, Chelsea.

Beldi H, Gimbert F, Maas S, Scheifler R, Soltani N. 2006. Seasonal variations of $\mathrm{Cd}, \mathrm{Cu}, \mathrm{Pb}$ and $\mathrm{Zn}$ in the edible mollusc Donax trunculus (Mollusca, Bivalvia) from the Gulf of Annaba, Algeria. African Journal of Agricultural Research 1: 85-90.

Bouaziz-Yahiatene H, Medjdoub-Bensaad F. 2016. Malacofauna diversity in Kabylia region (Algeria). Advances in Environmental Biology 10: 99-106.

Bouchet P, Rocroi JP, Frýda J, Hausdorf B, Ponder W, Valdés Á, Warén A. 2005. Classification and nomenclator of gastropod families. Malacologia : International Journal of Malacology 47: 1-397.

Boudechiche L. 2007. Biodiversité des hélicidés du Parc National d'ElKala (extrême nord-est Algérien). Bulletin de l'Institut National des Sciences et Technologie de la Mer (INSTM) 12: 12-123.

Bourguignat JR. 1864. Malacologie de l'Algérie ou histoire naturelle des animaux mollusqes terrestres et fluviatiles: recueilles jusqu'à ce jour dans nos possessions du nord de l'Afrique. Challamel Ainé, Paris. 
Chevallier H. 1977. La variabilité de l'escargot petit-gris Helix aspersa Müller. Bulletin du Museum d'Histoire Naturelle de Paris 448: 425442.

Colwell RK. 2009. Biodiversity: Concepts, Patterns, and Measurement. In: Levin SA, Carpenter SR, Godfray, HCJ, Kinzig AP, Loreau M, Losos JB, Walker B, Wilcove DS. (Eds) The Princeton Guide to Ecology. Princeton University Press, New Jersey.

Dajoz R. 1985. Précis d'Écologie. Dunod, Paris.

Damerdji A. 2008. Systématique et Bio-écologie de différents groupes faunistiques notamment les Gastéropodes et les Orthoptères selon un transect nord-sud Ghazaouet-El-Aricha. [Dissertation]. Institut National d'Agronomie. Algiers. [French]

Däumer C, Greve C, Hutterer R, Misof B, Haase M. 2012. Phylogeography of an invasive land snail: natural range expansion versus anthropogenic dispersal in Theba pisana pisana. Biological Invasions 14: 1665-1682.

De Francesco CG, Lagiglia H. 2007. A predatory land snail invades central-western Argentina. Biological Invasions 9: 795-798.

Frýda J, Rohr DM. 2004. Gastropods. In: Webby BD, Paris F, Droser ML, Percival IG. (Eds) The Great Ordovician Biodiversification Event Columbia University Press, New York.

Hamon RE, McLaughlin MJ, Naidu R, Correll R. 1998. Long-Term Changes in Cadmium Bioavailability in Soil. Environmental Science \& Technology 32: 3699-3703.

Itziou A, Dimitriadis VK. 2011. Introduction of the land snail Eobania vermiculata as a bioindicator organism of terrestrial pollution using a battery of biomarkers. Sci Total Environ 409: 1181-1192.

Larba R, Soltani N. 2013. Diversity of the terrestrial gastropods in the Northeast Algeria: spatial and temporal distribution. European Journal of Experimental Biology 3: 209-215.

Larba R, Soltani N. 2014. Use of the land snail Helix aspersa for monitoring heavy metal soil contamination in Northeast Algeria. Environmental Monitoring and Assessment 186: 4987-4995.

Magurran AE. 2004. Measuring Biological Diversity. Blackwell Publishing, Oxford.

Matsukuma A, Takeda S. 2009. An invasive snail Rumina decollato (Linnaeus, 1758) in Japan, with records of quarantine by the Plant Protection Station, Ministry of Agriculture, Forestry and Fisheries, Japan during 1997-2007. Bulletin of the Kyushu University Museum 7: $35-85$.

Morris EK, Caruso T, Buscot F, Fischer M, Hancock C, Maier TS, Meiners T, Müller C, Obermaier E, Prati D, Socher SA, Sonnemann I Wäschke N, Wubet T, Wurst S, Rillig MC. 2014. Choosing and using diversity indices: insights for ecological applications from the German Biodiversity Exploratories. Ecol Evol 4: 3514-3524.

Mulder CPH, Bazeley-White E, Dimitrakopoulos PG, Hector A, SchererLorenzen M, Schmid B. 2004. Species evenness and productivity in experimental plant communities. Oikos 107: 50-63.
Neubert E. 2014. Revision of Helix Linnaeus, 1758 in its eastern Mediterranean distribution area, and reassignment of Helix godetiana Kobelt, 1878 to Maltzanella Hesse, 1917 (Gastropoda, Pulmonata, Helicidae). Naturhistorisches Museum der Burgergemeinde.

Ondina P, Hermida J, Outeiro A, Mato S. 2004. Relationships between terrestrial gastropod distribution and soil properties in Galicia (NW Spain). Applied Soil Ecology 26: 1-9.

Pechenik JA. 2005. Biology of the Invertebrates. McGraw-Hill Higher Education, New York

Pfenninger M, Véla E, Jesse R, Elejalde MA, Liberto F, Magnin F, Ortí A. 2010. Temporal speciation pattern in the western Mediterranean genus Tudorella P. Fischer, 1885 (Gastropoda, Pomatiidae) supports the Tyrrhenian vicariance hypothesis. Mol Phylogenet Evol 54: 427436.

Poiret JLM. 1789. Voyage en Barbarie, ou lettres écrites de l'ancienne Numidie pendant les années 1785 et 1786, sur la religion, les coutumes et les moeurs des Maures et les Arabes-Bédouins avec un essai sur l'histoire naturelle de ce pays. J.B.F. Née de la Rochelle Librairie, Paris

Prévot V, Jordaens K, Sonet G, Backeljau T. 2013. Exploring Species Level Taxonomy and Species Delimitation Methods in the Facultatively Self-Fertilizing Land Snail Genus Rumina (Gastropoda: Pulmonata). PLoS ONE 8 (4): Pe60736. DOI: 10.1371/journal.pone.0060736

Rached-Mosbah O. 1993. Action de l'antimoine sur la végétation en zone steppique et étude de l'adaptation d'une espèce tolérante (Hedysarum pallidum Desf.). [Dissertation]. Museum National d'Histoire Naturelle. Paris. [French]

Rollo C. 1991. Endogenous and exogenous regulation of activity in Deroceras reticulatum, a weather-sensitive terrestrial slug. Malacologia 33: 199-220.

Sacchi CF. 1958. Les mollusques terrestres dans le cadre des relations biogéographiques entre l'Afrique du Nord et l'Italie. Vie et Milieu 9: 11-52.

Semadi A, Deruelle S. 1993. Détection de la pollution plombique à l'aide de transplants lichéniques dans la région de Annaba (Algérie). Pollution Atmospherique 140: 86-102.

Siddique I, Vieira ICG, Schmidt S, Lamb D, Carvalho CJR, Figueiredo RDO, Blomberg S, Davidson EA. 2010. Nitrogen and phosphorus additions negatively affect tree species diversity in tropical forest regrowth trajectories. Ecology 91: 2121-2131.

Solem A. 1984. A world model of land snail diversity and abundance. In: Solem A, Van Bruggen AC. (eds). Worldwide Snails: Biogeographical Studies on Non-marine Mollusca. Brill, Leiden.

Van Bruggen AC. 1995. Biodiversity of the Mollusca: time for a new approach. In: Van Bruggen AC, Wells SM, Kemperman TCM. (Eds). Biodiversity and conservation of the Mollusca. Backhuys Publisher, Oegstgeest-Leiden. 